US Army Corps of Engineers ${ }_{\circledast}$

Engineer Research and

Development Center

U.S. Air Force Rapid Airfield Damage Recovery (RADR) Modernization Program

\title{
Evaluation of Commercially Available Screeds for Finishing of Rapid-Setting Concrete
}

William D. Carruth

February 2019
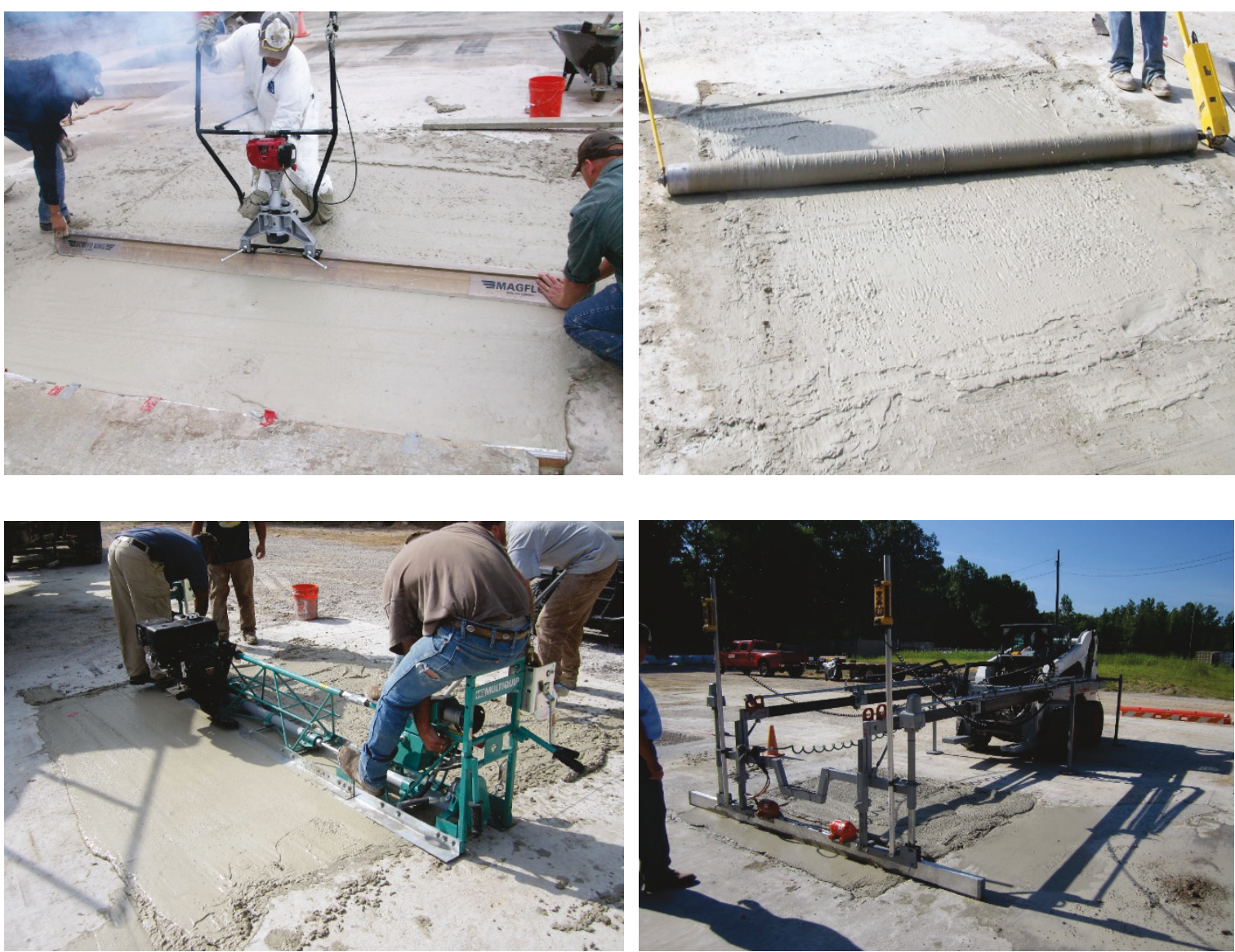
The U.S. Army Engineer Research and Development Center (ERDC) solves the nation's toughest engineering and environmental challenges. ERDC develops innovative solutions in civil and military engineering, geospatial sciences, water resources, and environmental sciences for the Army, the Department of Defense, civilian agencies, and our nation's public good. Find out more at www.erdc.usace.army.mil.

To search for other technical reports published by ERDC, visit the ERDC online library at http://acwc.sdp.sirsi.net/client/default. 


\title{
Evaluation of Commercially Available Screeds for Finishing of Rapid-Setting Concrete
}

\author{
William D. Carruth \\ Geotechnical and Structures Laboratory \\ U.S. Army Engineer Research and Development Center \\ 3909 Halls Ferry Road \\ Vicksburg, MS 39180-6199
}

Final report

Approved for public release; distribution is unlimited.

Prepared for Headquarters, Air Force Civil Engineer Center

Tyndall AFB, FL 32403-5319

Under Rapid Airfield Damage Repair (RADR) Modernization Program 


\section{Abstract}

The U.S. Air Force Civil Engineer Center (AFCEC) began the Rapid Airfield Damage Recovery (RADR) Modernization Program to develop technologies to address operational limitations of current RADR equipment, materials, and tactics. One of the most critical activities in the crater repair process is the finishing of rapid-setting concrete material used to cap repairs. Finished repairs must meet roughness quality criteria (RQC) in order to prevent damage to fighter aircraft. The concrete screeds used previously were consistently able to meet this criteria, however they required three dedicated personnel to operate. The quantity of crater repair team members is limited, so AFCEC desires a reduction in manpower requirements for rapid-setting concrete finishing. To address this shortfall, five commercially available screeds were evaluated by conducting a total of 14 crater repairs. Screeds were ranked according to the following attributes: (1) speed, (2) ease of setup and operation, (3) ease of transport, (4) operator exertion level, (5) cost, and (6) quality of finish. The number of personnel required to operate each screed was also recorded. The AutoSkreed ${ }^{\circledR}$ was recommended for consideration as a suitable screed, but several modifications are recommended. The vibratory manual screed and magnesium bar screed were recommended as preferred alternatives.

DISCLAIMER: The contents of this report are not to be used for advertising, publication, or promotional purposes. Citation of trade names does not constitute an official endorsement or approval of the use of such commercial products. All product names and trademarks cited are the property of their respective owners. The findings of this report are not to be construed as an official Department of the Army position unless so designated by other authorized documents. 


\section{Contents}

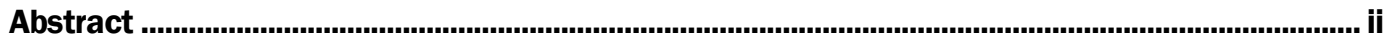

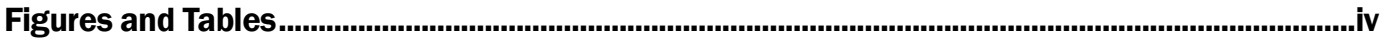

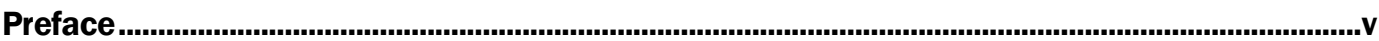

Unit Conversion Factors ...............................................................................................................

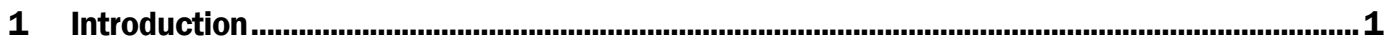

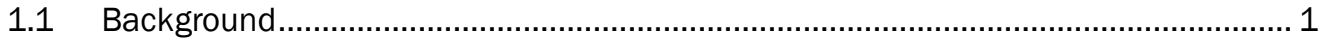

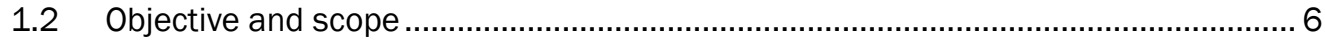

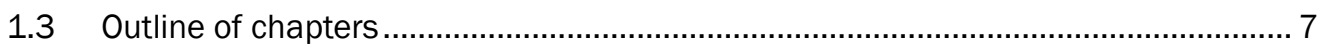

2 Description of Screeds and Test Procedures .............................................................................. 8

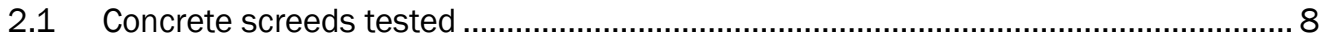

2.1.1 Manual vibratory screed ................................................................... 8

2.1.2 Magnesium bar screed .................................................................... 9

2.1.3 Roller screed ..................................................................................... 10

2.1.4 Vibratory truss screed .......................................................................... 11

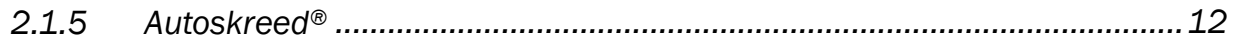

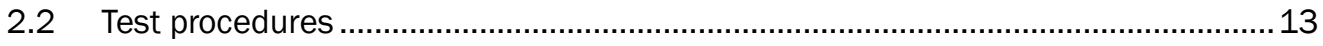

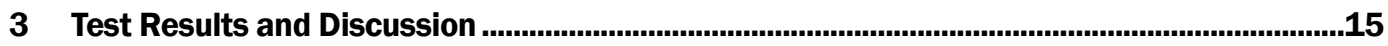

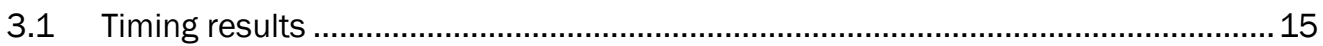

3.2 Screed observations, results, and discussion .............................................. 15

3.2.1 Manual vibratory screed testing ......................................................... 16

3.2.2 Magnesium bar screed testing ............................................................... 16

3.2.3 Roller screed testing ............................................................................ 17

3.2.4 Vibratory truss screed testing ............................................................... 18

3.2.5 Autoskreed ${ }^{\circledR}$ testing............................................................................... 19

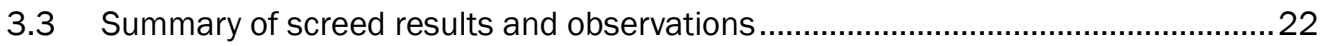

4 Conclusions and Recommendations .................................................................................24

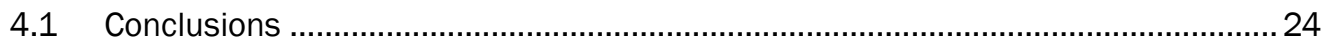

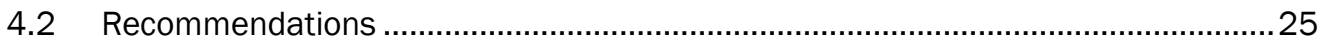

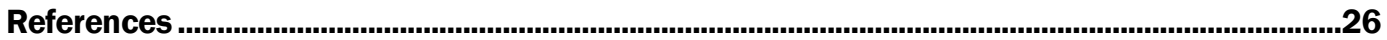

\section{Report Documentation Page}




\section{Figures and Tables}

\section{Figures}

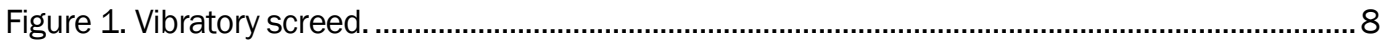

Figure 2. Magnesium bar screed...............................................................................................10

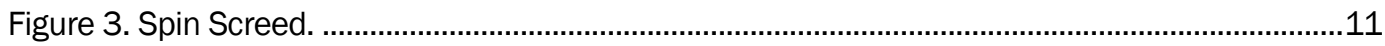

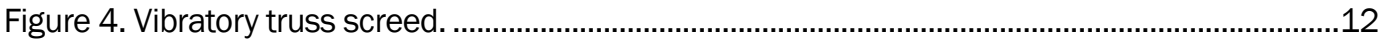

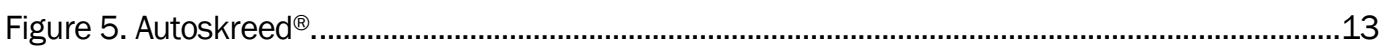

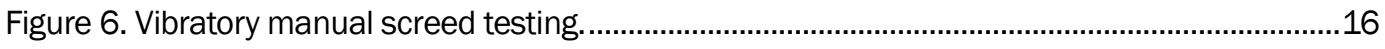

Figure 7. Magnesium bar screed testing.....................................................................................

Figure 8. Roller screed testing .............................................................................................................18

Figure 9 .Vibratory truss screed testing. ……………………………………………………....19

Figure 10. Vibratory truss screed crater repair surface finish. ........................................................19

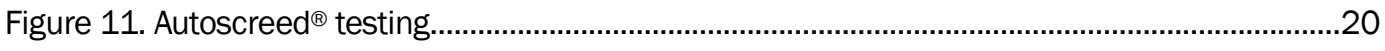

Figure 12. Autoskreed ${ }^{\circledR}$ surveying layout...................................................................................21

\section{Tables}

Table 1. Vibratory manual screed manufacturers and costs. ................................................................

Table 2. Roller screed manufacturers and costs. .............................................................................10

Table 3. Vibratory truss screed manufacturers and costs................................................................12

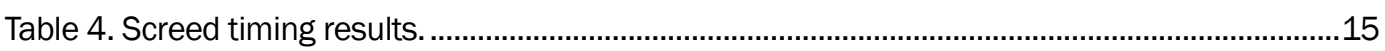

Table 5. Autoskreed ${ }^{\circledR}$ repair survey results......................................................................................2

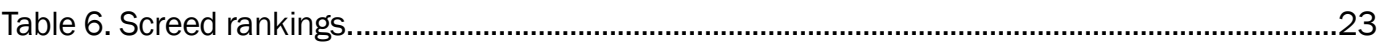




\section{Preface}

This study was conducted for the U.S. Air Force Civil Engineer Center (AFCEC), Tyndall Air Force Base, FL, under the Rapid Airfield Damage Recovery (RADR) Modernization Program. The program manager was Dr. Robert Diltz of AFCEC. Mr. Jeb S. Tingle provided technical oversight of the project for ERDC.

The work was performed by the Airfields and Pavements Branch (GMA) of the Engineering Systems and Materials Division (GM), U.S. Army Engineer Research and Development Center, Geotechnical and Structures Laboratory (ERDC-GSL). At the time of publication, Dr. Timothy W. Rushing was Chief, CEERD-GMA; Mr. Jeffrey G. Averett was Acting Chief, CEERD-GM; and Ms. Pamela G. Kinnebrew, CEERD-GZT, was Technical Director for Military Engineering. Mr. Charles W. Ertle II was Deputy Director, ERDC-GSL, and Mr. Bartley P. Durst was Director.

COL Ivan P. Beckman was the Commander of ERDC, and Dr. David W. Pittman was the Director. 


\section{Unit Conversion Factors}

\begin{tabular}{|c|c|c|}
\hline Multiply & By & To Obtain \\
\hline cubic feet & 0.02831685 & cubic meters \\
\hline cubic yards & 0.7645549 & cubic meters \\
\hline degrees Fahrenheit & $(\mathrm{F}-32) / 1.8$ & degrees Celsius \\
\hline feet & 0.3048 & meters \\
\hline gallons (US liquid) & $3.785412 \mathrm{E}-03$ & cubic meters \\
\hline inches & 0.0254 & meters \\
\hline pounds (force) & 4.448222 & newtons \\
\hline pounds (force) per square foot & 47.88026 & pascals \\
\hline pounds (force) per square inch & 6.894757 & kilopascals \\
\hline pounds (mass) per cubic foot & 16.01846 & kilograms per cubic meter \\
\hline tons ( 2,000 pounds, mass) per square foot & $9,764.856$ & kilograms per square meter \\
\hline
\end{tabular}




\section{Introduction}

\subsection{Background}

In March 2002, the Joint Airfield Damage Repair Working Group identified the lack of certification of existing airfield damage repair (ADR) methods for $\mathrm{C}-17$ aircraft as the number one repair issue requiring immediate attention. The U.S. Air Force (USAF) Air Mobility Command funded an effort by the U.S. Army Engineer Research and Development Center (ERDC) to evaluate existing ADR expedient repair technologies under $\mathrm{C}-17$ aircraft loads. The ERDC testing produced the following conclusions (Gartrell 2007; 2008):

1. Load cart testing verified that the legacy expedient repair systems provide adequate vertical load bearing support for current aircraft.

2. New anchor bolts were developed and recommended for anchoring current foreign object debris (FOD) cover mats to concrete pavements.

In 2005, the ERDC and the C-17 Systems Group conducted flight tests on the legacy expedient repair technologies at Plant 42 in Palmdale, CA. The following results were observed:

1. The current USAF technology consisting of a crushed stone backfill surfaced with folded fiberglass mat (FFM) survived medium-speed braking events and was deemed suitable for use on taxiways and aprons.

2. The current USAF FFM system failed under high-speed taxi events due to the formation of a bow wave and the subsequent failure of the fiberglass mat component of the system.

3. The U.S. Army system, consisting of a sand grid reinforced backfill surfaced with fiberglass reinforced polyester (FRP) panels, failed under medium-speed braking events due to failure of the connector bushings. After replacement with more robust connector bushings from the FFM system, the FRP system withstood the high-speed taxi events that caused the FFM to fail.

4. AM2 aluminum matting was successfully tested as a suitable expedient ADR technology for taxiways and aprons but could not be used on runway surfaces due to the potential roughness associated with its inherent profile thickness. 
The most significant shortfall noted from the evaluation of the legacy ADR expedient repair technologies was that none of the repair technologies were capable of supporting $\mathrm{C}-17$ aircraft on a runway where high, horizontal braking forces caused the systems to fail. For C-17 operations only, the repairs can be performed without the protective mat surfacing or FOD cover. However, protective surfacing or FOD covers are required for fighter aircraft operations. Thus, the legacy repair technologies cannot be used on airfields subjected to both fighter and heavy cargo aircraft, due to the inability of the current systems to sustain $\mathrm{C}-17$ operations and the inability of fighter aircraft to operate on unsurfaced repairs.

In 2006, the Critical Runway AssessmenT and Repair (CRATR) Joint Capabilities Technology Demonstration (JCTD) was initiated. The CRATR JCTD intended to provide a method of rapidly assessing and repairing damage to an airfield. The JCTD's goal was to develop capabilities to return damaged runways (repairing up to 100 small craters) to full operational sortie production in less than $8 \mathrm{hr}$. The CRATR JCTD included three major technology demonstrations. These demonstrations included two limited operational utility assessments (LOUAs) and one operational utility assessment (OUA). LOUA1 was conducted at Silver Flag Exercise site, Tyndall AFB, FL, during the period August-October 2008 (Tingle et al. 2009). LOUA1 was conducted to evaluate materials, tactics, techniques, and procedures (TTPs), and prototype equipment for rapid automated airfield damage assessment and crater repair. General conclusions and recommendations from LOUA1 are summarized below:

1. The addition of multi-terrain loaders (MTLs) to ADR equipment packages was recommended due to maneuverability in confined locations and versatility in performing many ADR tasks.

2. A combination of an MTL with a wheel saw, such as the Caterpillar 277 C with a Caterpillar SW45, was very successful in saw-cutting upheaved pavement sections.

3. The Caterpillar M322D and the Volvo EW18oC excavators both proved to be suitable for excavation purposes. A larger area plate compactor attachment for either excavator was recommended when used for compacting granular backfill.

4. Expandable foam backfill performed well under traffic tests when surfaced with rapid-setting cementitious caps; however, the foam required reformulation to increase pot life and reduce water sensitivity. 
5. It was recommended that the foam dispenser prototype be redesigned to improve the ease of operation, uniformity of foam distribution, and maintenance activities. The production capacity of the foam dispenser needed to be variable and increased by as much as $500 \%$.

6. The rapid-setting cementitious capping materials performed well under traffic tests.

7. Based on the evaluation of several mixer configurations, recommendations were to develop a simplified volumetric mixer that could be factory calibrated to several rapid-setting materials.

8. Based on evaluation of a pelletized asphalt (AC) dispenser and material, recommendations were to increase production capacity of the mixer and improve packaging and loading of materials.

9. The pelletized AC performed well under traffic tests but required improved placement techniques.

10. The modified FRP and anchoring systems performed well during the demonstration, given their intended purpose of withstanding expedient pass levels of 100. The expedient repairs did not meet the CRATR JCTD objective of 900-3,000 passes of combined heavy and fighter traffic.

11. The isolation of individual tasks during LOUA1 obscured the true timeline for completion of the entire repair. This method did not consider efficiencies in working from beginning to end on a single crater and resulted in unrealistic total repair times when the times for each task were simply summed. It was anticipated that additional efficiency would be achieved after the specialized equipment was refined and added to inventory, the units were properly trained in the methods used, and the employment procedures were refined for maximum efficiency.

Following material and equipment modifications, LOUA2 was conducted at Silver Flag Exercise site, Tyndall AFB, FL, during April 2009 (Priddy et al. 2013a). LOUA2 was conducted to further evaluate materials, TTPs, and prototype equipment for crater repair. General conclusions and recommendations from LOUA2 are summarized below:

1. MTLs and wheeled excavators with multiple attachments continued to show versatility in multiple ADR tasks and maneuverability in confined locations. 
2. A combination of an MTL with a wheel saw, such as the Caterpillar $277 \mathrm{C}$ with a Caterpillar SW45, was successful in saw-cutting upheaved pavement sections for both thick and thin pavements.

3. Following reformulation, the modified expandable foam backfill performed well under traffic tests when surfaced with rapid-setting cementitious caps.

4. Modifications to the foam dispenser provided easier operation, increased dispenser rates, and reduced time required to backfill each crater. Modification to the foam and the foam dispenser provided more uniform rise of foam backfill. Additional modifications to the foam dispenser were recommended to eliminate the requirement for a separate flushing system for maintenance activities.

5. Rapid-setting flowable fill provided an alternative to compacted soil or aggregates and expandable foam for backfilling damaged pavements. Placed dry, the material did not require mechanical mixing and performed well during traffic tests when surfaced with rapid-setting concrete caps. When placed wet, the material performed well under AC caps.

6. Based on recommendations from LOUA1, the simplified volumetric mixer was successfully factory calibrated to several rapid-setting materials. Simultaneous loading and dispensing of material reduced the time required to place rapid-setting cementitious caps. Recommendations to improve the system included increasing the capacity of the onboard water tanks, improving the maneuverability of the equipment, and providing easier loading of materials.

7. Following redesign and reformulation, the pelletized AC mixer successfully produced small batches of hot mix asphalt that could be rapidly graded and compacted for airfield surfaces.

Successfully demonstrated technologies from LOUA2 were down-selected for a final OUA demonstration. The OUA demonstration was conducted at Avon Park Air Force Range, FL, during August 2009 (Priddy et al. 2013b). The OUA was conducted to further refine the materials, TTPs, and prototype equipment for crater repair. General conclusions and recommendations from the OUA are summarized below:

1. The CRATR method TTPs developed for rapid-setting and pelletized AC capped repairs were adequate to accomplish the ADR repair mission. Repair sequences that did not meet the 6.5-hr return to service requirement were due to equipment failures and lightning 
delays. The repair sequence and team breakdown/flow worked well for all sequences.

2. Communication between the crater chief and the haul team is vital to the prompt delivery and unloading of materials and the completion of repair activities.

3. The wheel saw attachment worked well for thick and thin PCC, as long as dowel bars were not encountered. However, a standard walk-behind concrete saw was helpful when cutting through dowels in concrete pavement.

4. With regard to excavation, debris should be kept as large as possible to prevent delays in removal. Additionally, switching attachments for an excavator resulted in delays in performing repair tasks.

5. Buildup of rapid-setting material near the conveyor of the volumetric mixer should be promptly removed following use. Care is required when filling the wash-out tank to prevent moisture from getting into the hopper.

6. Excess mix water in rapid-setting caps resulted in longer finishing times and increased labor to maintain the runway crown. This also creates high FOD potential if not immediately removed. Excessive finishing of the rapid-setting caps with the vibratory screed also results in an overworked surface (i.e., shrinkage cracking) and weakened edges. Care must be taken to prevent feathering the edges of the crater caps to avoid FOD potential.

In general, the OUA demonstration validated that the new materials, equipment, and procedures are capable of meeting the required ADR timeline and sustaining aircraft traffic. Based on the results of the OUA, the decision to begin refinement and procurement of the new ADR technologies was made by the USAF.

Since the OUA was conducted, numerous troop demonstrations and other full-scale tests have been conducted to address other gaps identified in the crater repair process. These include conducting repairs in cold weather (Edwards et al. 2013; Edwards et al. 2018) and wet weather (Bell et al. 2013; Bell 2017; and Bell et al. 2018) and performing large crater repairs (Carruth et al. 2015). Additional work has also been conducted on equipment refinement (Bell et al. 2015; Bell and Rowland 2017) and examining the structural performance of rapid-setting concrete (Priddy et al. 2016) and rapid-setting flowable fill (Carruth and Howard 2016). 
A description of the crater repair process is documented in many of the references cited above (Bell et al. 2013; Priddy et al. 2013b; Edwards et al. 2013; and Carruth et al. 2015). First, large debris is removed with track loaders and large front-end loaders. Next, the stanchion method is used (USAF 1992) to mark the extent of upheaval before a square repair area on the pavement is marked. The marked area is then saw cut, followed by breaking and removal of the existing material with wheeled excavators. Once the repair is excavated, it is backfilled, typically with rapid-setting flowable fill or compacted crushed stone. The repair is capped with rapidsetting concrete (RSC) by using the U.S. Air Force Simplified Volumetric Mixer (SVM).

One of the most critical activities in the crater repair process is the finishing of the rapid-setting concrete material used to cap crater repairs. Finished repairs must meet repair quality criteria (RQC). The AFCEC Interim RADR Tactics, Techniques, and Procedures (TTPs) (AFCEC 2018) prescribe RQC as defined in Air Force Technical Order 35E2-5-1 (USAF 1992), which allows repairs to extend $0.5 \mathrm{in}$. above or $1 \mathrm{in}$. below the surrounding pavement (+0.5/-1.0 in). While the concrete screeds used previously have consistently been able to meet this criteria, they require two or three personnel to operate. Due to limitations on the size of the repair team and the physical requirements of screeding rapid-setting concrete, it is desirable to reduce the manpower requirements for this activity. In addition, several comments have been recorded during after action reviews (AARs) in previous troop demonstrations describing how cumbersome the current screeds are to operate.

\subsection{Objective and scope}

The objective of the testing described in this report was to evaluate commercially available concrete screeds for finishing rapid-setting concrete. A screed is required that can be operated by one or two personnel and is less cumbersome to use so that repairs can be finished properly to support designated aircraft types (i.e., transports, fighters, and tankers). The screed also must be able to finish larger repairs, up to $15 \mathrm{ft}$ by $15 \mathrm{ft}$.

The scope included physical testing of the selected screeds to place and finish RSC using ERDC personnel. Timing results and observations were recorded, along with interviews with ERDC technicians after each test, to document any advantages or disadvantages of each screed tested. Photographs were obtained of each finished surface as a means of 
assessing quality, and elevation measurements were obtained in some cases. Overall, the screeds tested were ranked for speed, ease of use and setup, ease of transport, exertion level of operators, cost, and quality of finish provided. Average rankings for each screed were calculated and provided along with the overall conclusions and recommendations developed.

\subsection{Outline of chapters}

Chapter 1 provides background information covering the history of the ADR program and the specific objectives and scope of the work covered in this report. Chapter 2 presents a description of the screeds tested, test methods, and data collection. Chapter 3 provides the results from testing and a discussion of these results. Conclusions and recommendations are provided in Chapter 4, and references used in preparing this report are also included. 


\section{Description of Screeds and Test Procedures}

\subsection{Concrete screeds tested}

Five screeds were evaluated as part of the testing described in this report. The screeds were evaluated by conducting a total of 14 simulated crater repairs. Manufacturers of each screed along with relevant specifications, limitations, and cost are provided in this section.

\subsubsection{Manual vibratory screed}

Figure 1 shows the manual vibratory screed used in previous RADR testing and demonstrations including the Operational Utility Assessment (OUA) (Priddy et al. 2013b), ADR Cold Weather Demonstration (Edwards et al. 2013), ADR Wet Weather Demonstration (Bell et al. 2013), and ADR Large Crater Demonstration (Carruth et al. 2015). Several manufacturers make a product similar to the one shown in Figure 1. Table 1 lists manufacturers discovered during a market survey, along with estimated costs for the power head and a 10-ft screed board. Each of these models functions in a similar manner. The screed bar is designed to strike off and float the concrete simultaneously, and the small attached power head provides vibration to remove pockets of air that may exist in the concrete. Several different screed bar lengths are available, from $5 \mathrm{ft}$ to $16 \mathrm{ft}$. The Wyco Screed King was used for the testing described herein.

Figure 1. Vibratory screed.

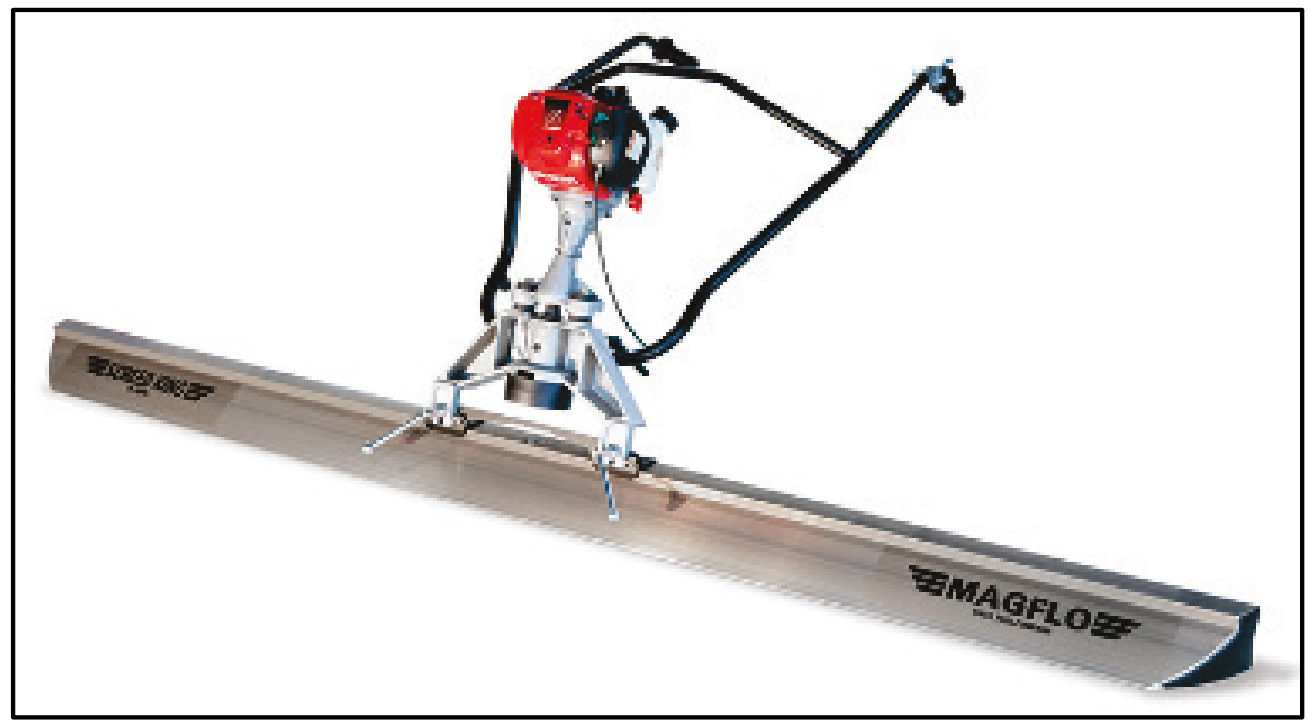


Table 1. Vibratory manual screed manufacturers and costs.

\begin{tabular}{|c|c|c|c|c|c|}
\hline Manufacturer & Power Head Model & $\begin{array}{l}\text { Power Head } \\
\text { Cost }\end{array}$ & $\begin{array}{l}\text { 10-ft Screed } \\
\text { Model No. }\end{array}$ & $\begin{array}{l}\text { 10-ft Screed } \\
\text { Cost }\end{array}$ & Total Cost \\
\hline MBW & ScreeDemon ${ }^{\mathrm{TM}}$ & $\$ 1,550$ & 17810 & $\$ 460$ & $\$ 2,010$ \\
\hline Northrock & PR03200 Series & $\$ 1,450$ & 49398 & $\$ 340$ & $\$ 1,790$ \\
\hline Wyco & Screed King & $\$ 1,380$ & WS621420 & $\$ 550$ & $\$ 1,930$ \\
\hline Northstar ${ }^{\circledR}$ & 49398 & $\$ 1,300$ & 49163 & $\$ 250$ & $\$ 1,550$ \\
\hline Marshalltown & Shockwave & $\$ 1,900$ & SWSBlade10 & $\$ 750$ & $\$ 2,650$ \\
\hline Wacker Neuson & P35A & $\$ 1,675$ & SB10F & $\$ 500$ & $\$ 2,175$ \\
\hline
\end{tabular}

Using the vibratory screed is somewhat cumbersome, since the main operator must step into the repair and drag the screed across to strike off the material. The operator must wear protective gear and rubber boots during operation. Also, the edges of the screed bar must often be held down manually by two other personnel in order to ensure the repair is struck off evenly. The advantages of this screed include ease of transport, relatively low cost, and satisfactory performance in troop demonstrations. The vibratory screed is currently included in the USAF Sustainment Pavement Repair (SuPR) kit and ADR Tool Trailer.

\subsubsection{Magnesium bar screed}

Another type of screed that has been used successfully in previous ADR demonstrations is a simple magnesium bar screed (Figure 2). The crosssection dimensions of the bar screed are 1.5 in. by $3.5 \mathrm{in}$., and many different lengths are available. The weight of the $10-\mathrm{ft}$ version used during testing is approximately $12 \mathrm{lb}$, and the estimated cost is $\$ 200$. The advantages of the magnesium bar screed are that it is durable enough to resist warping after repeated use and can easily be moved between repairs since it is lighter than similar screeds made of other materials (e.g., wood or steel). However, the magnesium bar screed does not provide any vibration and is difficult to maneuver if the concrete material has a thick consistency. The magnesium bar screed is also included in the USAF SuPR kit. 
Figure 2. Magnesium bar screed.

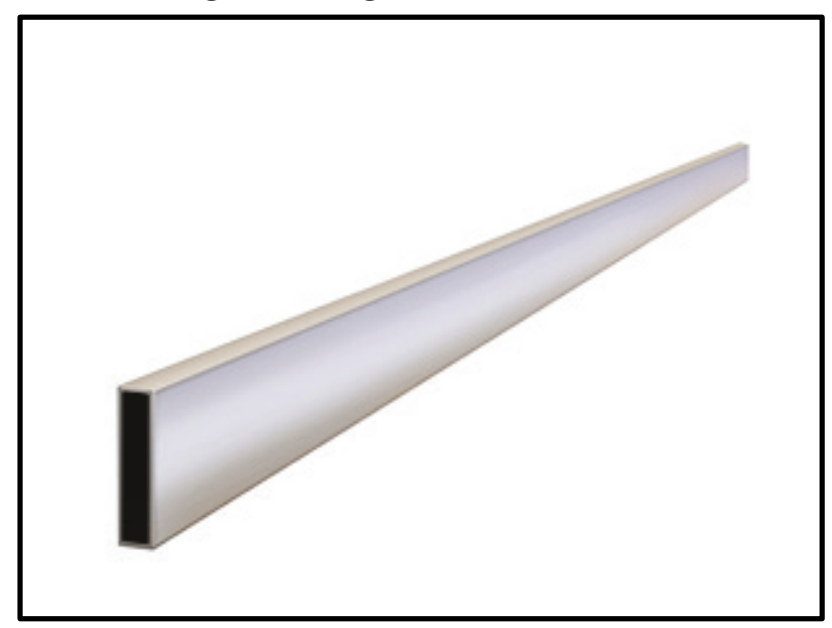

\subsubsection{Roller screed}

A roller screed (Figure 3) was also evaluated. A number of roller screeds were identified during an initial market survey conducted before testing, and some details are provided in Table 2. The Spin Screed ${ }^{\circledR}$ is lightweight, is easily maneuverable between craters, and utilizes spinning aluminum pipes of varying lengths to strike off the concrete. Lengths are available in $1-\mathrm{ft}$ increments from $1 \mathrm{ft}$ to $20 \mathrm{ft}$. The power to spin the pipes is provided by a standard angle drill on one end and a non-powered receiver on the other end. Both ends have handles so the screed can be guided across the repair during the screeding process. A $120 \mathrm{~V}$ power source with a standard grounded outlet is required to operate the angle drill. According to the manufacturer, the spin screed is capable of screeding concrete that exhibits a slump of 3 in. or greater. The spin screed works by floating on the surface of the concrete and moving the material surcharge in the direction of screeding, thus leveling the material behind the screed.

Table 2. Roller screed manufacturers and costs.

\begin{tabular}{|l|l|l|l|l|l|}
\hline & $\begin{array}{l}\text { Base } \\
\text { Assembly } \\
\text { Model No. }\end{array}$ & $\begin{array}{l}\text { Base } \\
\text { Assembly } \\
\text { Cost }\end{array}$ & $\begin{array}{l}\text { 10-ft Screed } \\
\text { Pipe Model No. }\end{array}$ & $\begin{array}{l}\text { 10-ft Screed Pipe } \\
\text { Estimated Cost }\end{array}$ & Total Cost \\
\hline Spin Screed ${ }^{\circledR}$ & $\begin{array}{l}\text { Assembly \& } \\
\text { Drill }\end{array}$ & $\$ 1200$ & $\begin{array}{l}\text { Spin Screed } \\
\text { Pipe }\end{array}$ & $\$ 225$ & $\$ 1,425$ \\
\hline Marshalltown & RS14 & $\$ 1450$ & RS14TUBE10 & $\$ 325$ & $\$ 1,775$ \\
\hline Multivibe & WCE & N/A & N/A & N/A & N/A \\
\hline
\end{tabular}


Figure 3. Spin screed.

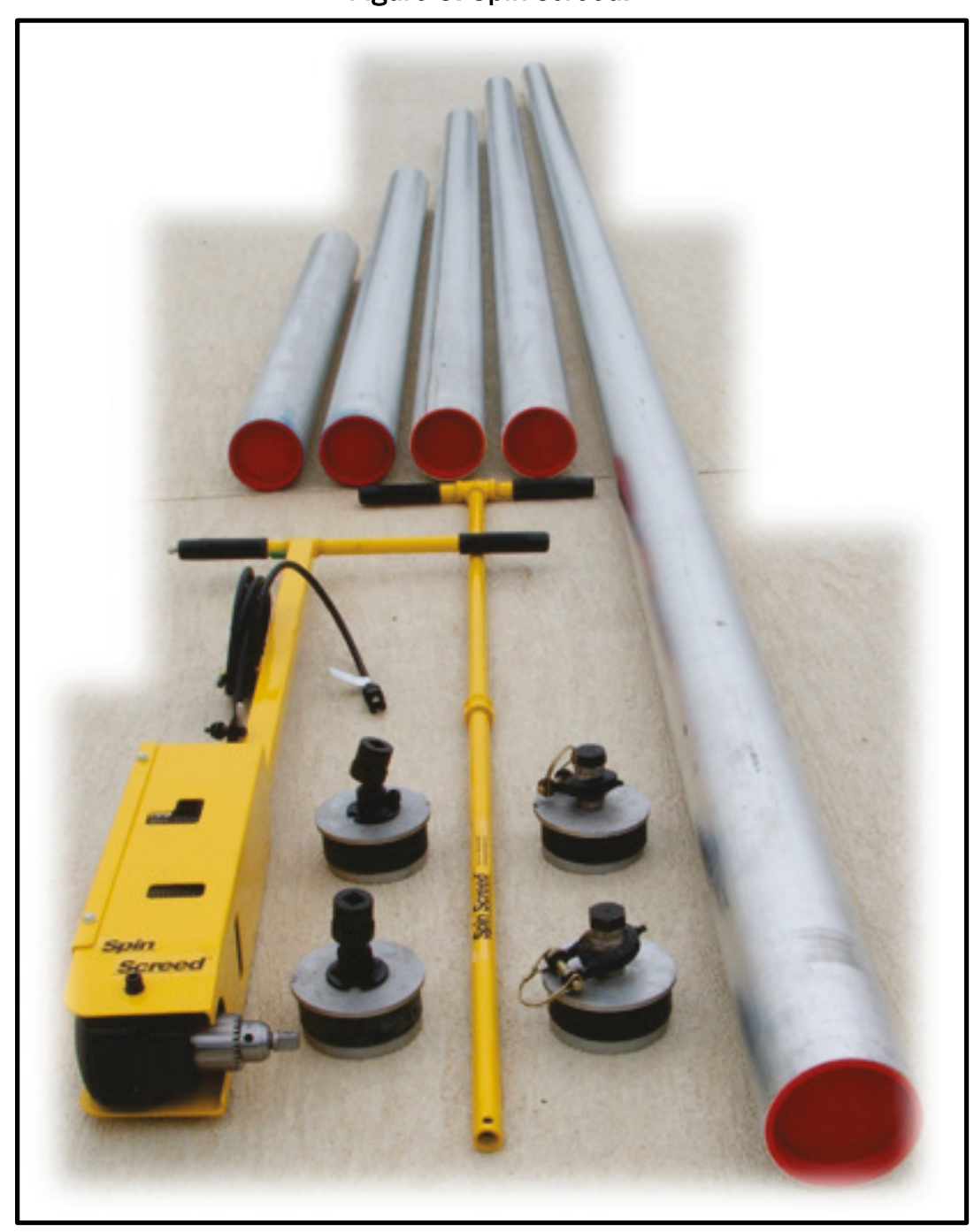

\subsubsection{Vibratory truss screed}

A standard vibratory truss screed (Figure 4) was included in the testing program. The model used was the Multiquip ${ }^{\circledR}$ WSHE50KIT11H, which is included in the USAF SuPR kit, but models are available from other manufacturers, as shown in Table 3. The screed has a modular design to enable the length to be adjusted very easily. The base screed includes a 7.5-ft-long section with an 11-HP engine to provide vibration and one of the automatic winches. Five-ft sections of truss screed can be added only to the base screed, and then a 2.5 -ft section that includes the other powered winch is installed on the opposite end. Manual cranks for the winches are also included for redundancy. The sections included in the SUPR kit can be assembled to produce a 25 - $\mathrm{ft}$-long screed. An assembled 10-ft screed was used for the testing described in this report. This 
configuration weighs $241 \mathrm{lb}$, and each additional 5 -ft section weighs $95 \mathrm{lb}$. The weight of the screed is designed to prevent the screed from riding up over stiffer concrete mixes, but a forklift is required to move the screed between repairs. Another option is to use the screed dolly accessory (included in the SuPR kit) to move the screed shorter distances. According to the manufacturer, the product is designed to screed concrete with a slump of 3 in. or greater.

Figure 4. Vibratory truss screed.

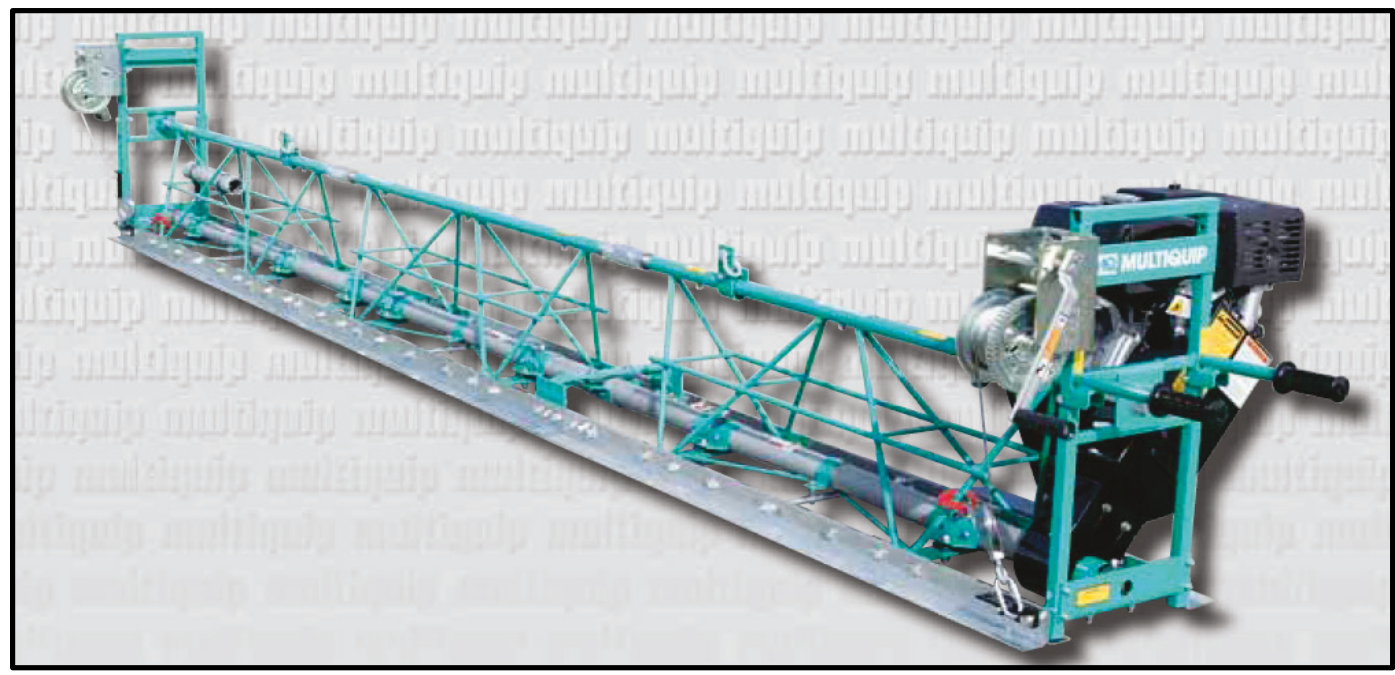

Table 3. Vibratory truss screed manufacturers and costs.

\begin{tabular}{|l|l|l|}
\hline \multicolumn{1}{|c|}{ Manufacturer } & \multicolumn{1}{|c|}{$\begin{array}{c}10-\mathrm{ft} \text { Assembly } \\
\text { Model No. }\end{array}$} & $\begin{array}{c}\text { Estimated Total } \\
\text { Cost }\end{array}$ \\
\hline Multiquip & WSHE75 & $\$ 2,300$ \\
\hline Marshalltown & TS10S & $\$ 2,100$ \\
\hline Allen Engineering & SE12 & N/A \\
\hline
\end{tabular}

\subsection{5 $\quad$ Autoskreed $^{\circledR}$}

The Autoskreed ${ }^{\circledR}$ is a screed attachment for a skid steer loader that utilizes a hydraulically powered reach system to extend over the repair, lower the screed bar, and then retract to strike off the placed concrete. The Autoskreed ${ }^{\circledR}$ is capable of being operated by one person. The bar used for testing was $12 \mathrm{ft}$ long, but the bar can be replaced with shorter or longer bars as needed. The bar is also equipped with two hydraulically powered motors that provide vibration. Power for the hydraulic motors was provided by the battery on the skid steer loader during testing. Estimated cost for the commercially available version of the Autoskreed ${ }^{\circledR}$ is over $\$ 75$,000. However, pricing could change depending on quantity and any future reductive modifications. 
Figure 5. Autoskreed ${ }^{\circledR}$.

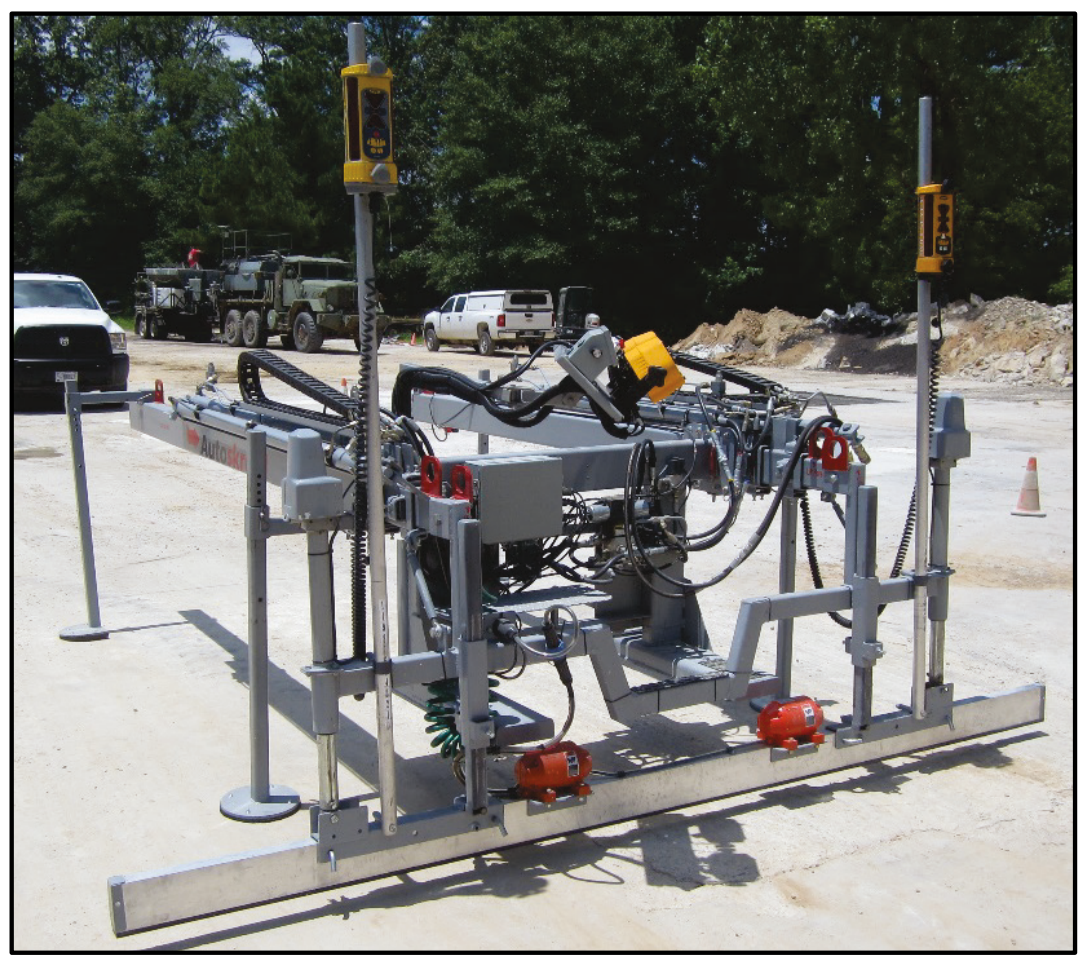

\subsection{Test procedures}

In order to evaluate each screed, 14 simulated crater repair tests were conducted. The target size for each crater repair was $8.5 \mathrm{ft}$ by $8.5 \mathrm{ft}$. This size was selected in order to maintain consistency with previous small crater demonstrations and tests (Bell et al. 2013; Edwards et al. 2013; Carruth and Howard 2016; Priddy et al. 2016). The craters were excavated and backfilled with crushed stone base material until a depth of approximately $10 \mathrm{in.}$ remained, which is also consistent with previous testing. The repairs were filled with CTS Rapid-Set Concrete Mix ${ }^{\circledR}$, screeded, and finished. Rapid-Set Concrete $\mathrm{Mix}^{\circledR}$ has been used extensively as a crater capping material in previous full-scale tests, demonstrations (Bell et al. 2013; Edwards et al. 2013; Carruth et al. 2015; Priddy et al. 2016), and live aircraft testing (Priddy et al. 2011). The main cementitious component in the mix is Rapid Set Cement, a proprietary, calcium sulfoaluminate-based material that accelerates the hardening time. The aggregate within the mix is $3 / 8$-in.maximum-size pea gravel. The dry blend of cementitious material and aggregate is stored in large 3,00o-lb super sacks outfitted with woven geotextile and lined with plastic. The pre-blended material requires only the addition of water, does not require the use of local aggregates, and can be mixed by using a variety of equipment including buckets with paddle mixers, mortar mixers, commercial volumetric mixers, and rotating drum 
transit trucks. Following development and validation in previous ADR Modernization Program projects, a simplified volumetric mixer was identified as the fastest method of mixing and placing rapid-setting concrete (Priddy et al. 2013b).

Bulk citric acid can be added to the mix water to increase the working time of the material and to prevent flash setting of material within the mixer at air temperatures greater than $85^{\circ} \mathrm{F}$. Aluminum sulfate can be added in bulk to accelerate the set time of the mix for placement of repairs at air temperatures less than $40^{\circ} \mathrm{F}$. The material is placed similarly to ordinary concrete with the exception that it hardens within $30 \mathrm{~min}$ and can sustain heavy aircraft traffic within $2 \mathrm{hr}$. Laboratory results have shown that this material achieves unconfined compressive strengths in excess of 3,000 psi after $2 \mathrm{hr}$ and over 5,000 psi after 28 days (Priddy et al. 2007).

During crater capping, the rapid-set concrete mix is typically placed with a more fluid consistency than conventional portland cement concrete (PCC). A thicker consistency is not only more difficult to strike off, but less water in the mix results in less retarder (citric acid), since the retarder is added to the mix water. A lower amount of retarder means that the material will quickly achieve initial set, making it very difficult to strike off and finish. Experience has shown that despite a more fluid consistency, the material has regularly met compressive strength requirements and withstood the required amount of traffic (Bell et al. 2013; Edwards et al. 2013; Carruth et al. 2015; Priddy et al. 2016).

Photographs were taken of the screeding and the finished repair surfaces, and screed times were recorded. Two craters that were finished with the Autoskreed ${ }^{\circledR}$ were surveyed with a rod and level in order to ensure that the crater met RQC requirements for fighter aircraft. Repairs finished with the manual vibratory screed and magnesium bar screed were not surveyed, but these screeds have shown the ability to strike off and finish repairs capped with RSC that successfully meet the RQC requirement (Edwards et al. 2013; Bell et al. 2013; Priddy et al. 2016). Repairs finished with the roller screed were not surveyed, since the finish produced by this screed was unacceptable, as discussed later in Section 3.2.3. Notes were recorded during testing regarding ease of use and setup, ease of transport, and exertion level of operators. These notes are discussed further in the following chapter. 


\section{Test Results and Discussion}

\subsection{Timing results}

Table 4 shows timing results for each screed tested. Individual test times are shown to the nearest minute along with the average times for each screed type. The screed times do not include any set-up time or any finishing activities that occurred after screeding. Some finishing with hand trowels is occasionally required to smooth any exceedingly rough areas of the repair, but this extra finishing is kept to a minimum. Any excess material must also be promptly removed by using flat shovels and trowels.

Table 4. Screed timing results.

\begin{tabular}{|l|c|c|}
\hline Screed type & \multicolumn{1}{|l|}{ Test \# } & Screed time (min) \\
\hline Manual vibratory screed & 1 & 2 \\
\cline { 2 - 3 } & 2 & 5 \\
\cline { 2 - 3 } & 3 & 4 \\
\cline { 2 - 3 } & AVG & 3.7 \\
\hline Magnesium bar screed & 1 & 2 \\
\cline { 2 - 3 } & 2 & 4 \\
\cline { 2 - 3 } & 3 & 1 \\
\cline { 2 - 3 } & AVG & 2.3 \\
\hline Roller screed & 1 & 2 \\
\cline { 2 - 3 } & 2 & 2 \\
\cline { 2 - 3 } & 3 & 1 \\
\cline { 2 - 3 } & AVG & 1.7 \\
\hline Truss screed & 1 & 3 \\
\cline { 2 - 3 } & 2 & 5 \\
\cline { 2 - 3 } & AVG & 4.0 \\
\hline Autoskreed & & 6 \\
\cline { 2 - 3 } & 1 & 7 \\
\cline { 2 - 3 } & 2 & 4 \\
\cline { 2 - 3 } & 3 & 5.7 \\
\cline { 2 - 3 } & AVG & \\
\cline { 2 - 3 } & & 2 \\
\hline
\end{tabular}

\subsection{Screed observations, results, and discussion}

This section provides photographs of each screed during testing along with a discussion of ease of use and setup, ease of transport, exertion level of operators, and quality of finish observations. 


\subsubsection{Manual vibratory screed testing}

Figure 6 shows the manual vibratory screed during testing. The screed was easy to set up and operate. Due to its lighter weight relative to some of the other screeds, it is also easily transported between repairs. However, as shown in Figure 6, one of the major disadvantages of this screed is the requirement for one person to actually step into the repair during screeding, which can be cumbersome and requires extra safety protection (plastic suit and rubber boots). Also, two other personnel are typically required to hold down the ends of the screed to ensure a flush repair, particularly for rapid-setting concrete mixtures with a thicker consistency (lower slump). The shape of the screed bar and vibration did provide a quality finished surface, as shown in Figure 6. Using this screed was moderately strenuous, which could lead to fatigue after multiple repairs are conducted consecutively.

Figure 6. Vibratory manual screed testing.

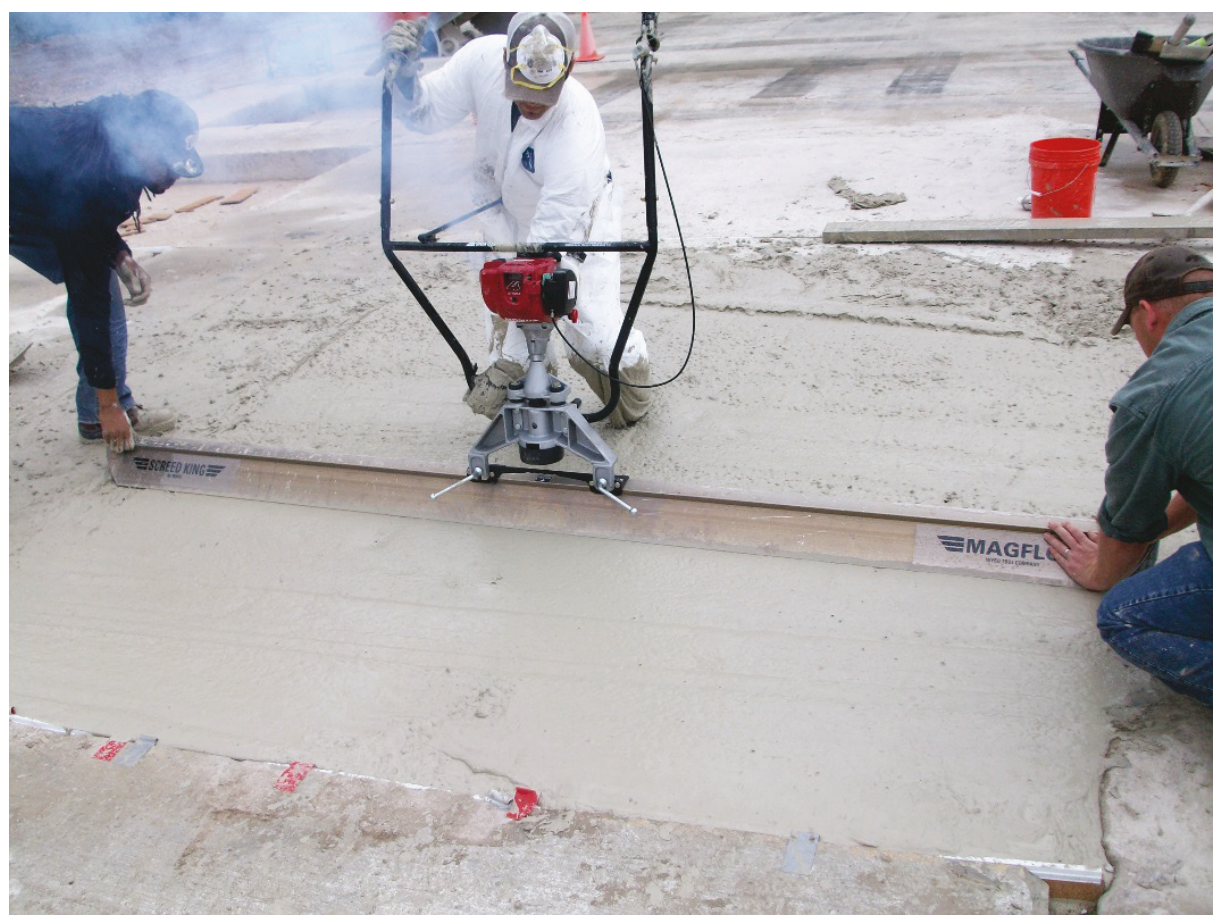

\subsubsection{Magnesium bar screed testing}

Testing of the magnesium bar screed is shown in Figure 7. The bar screed was the easiest screed to transport, and no set-up time is needed. Only two personnel were required to operate the screed. As shown in Figure 7, some small ridges of material were observed where the screed was placed at different points across the repair during multiple passes. If these ridges 
are not smoothed out quickly, the material reaches initial set and the small ridges become permanent. The lack of vibration also likely contributed to this observation. Overall, the screed provided an adequate finish during testing. For rapid-setting concrete mixtures with a more fluid consistency (higher slump), the magnesium bar screed worked well. However, mixtures with a thicker consistency were much more difficult to strike off. Moving the screed back and forth across the repair while applying sufficient pressure to strike off thicker material is strenuous and could lead to fatigue after multiple crater repairs are conducted.

Figure 7. Magnesium bar screed testing.

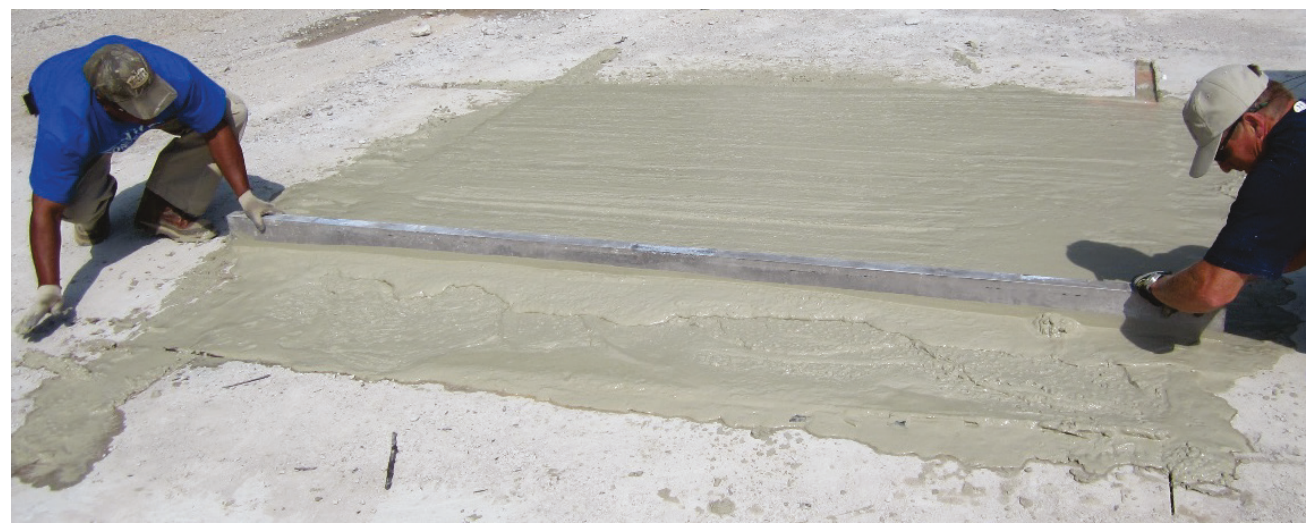

\subsubsection{Roller screed testing}

The roller screed during operation is shown in Figure 8. The roller screed did require some set-up time since an external power source (i.e., a generator) must first be moved into position, which also made the screed assembly relatively cumbersome to transport without a vehicle. While the roller screed required only two personnel to operate, the finish did not appear as smooth as those of the other screeds. Also, the power cord for the drive end of the screed could become an obstruction during operation. The screed required minimal exertion to operate and did exhibit the fastest screed times, as noted in Table 4. 
Figure 8. Roller screed testing.

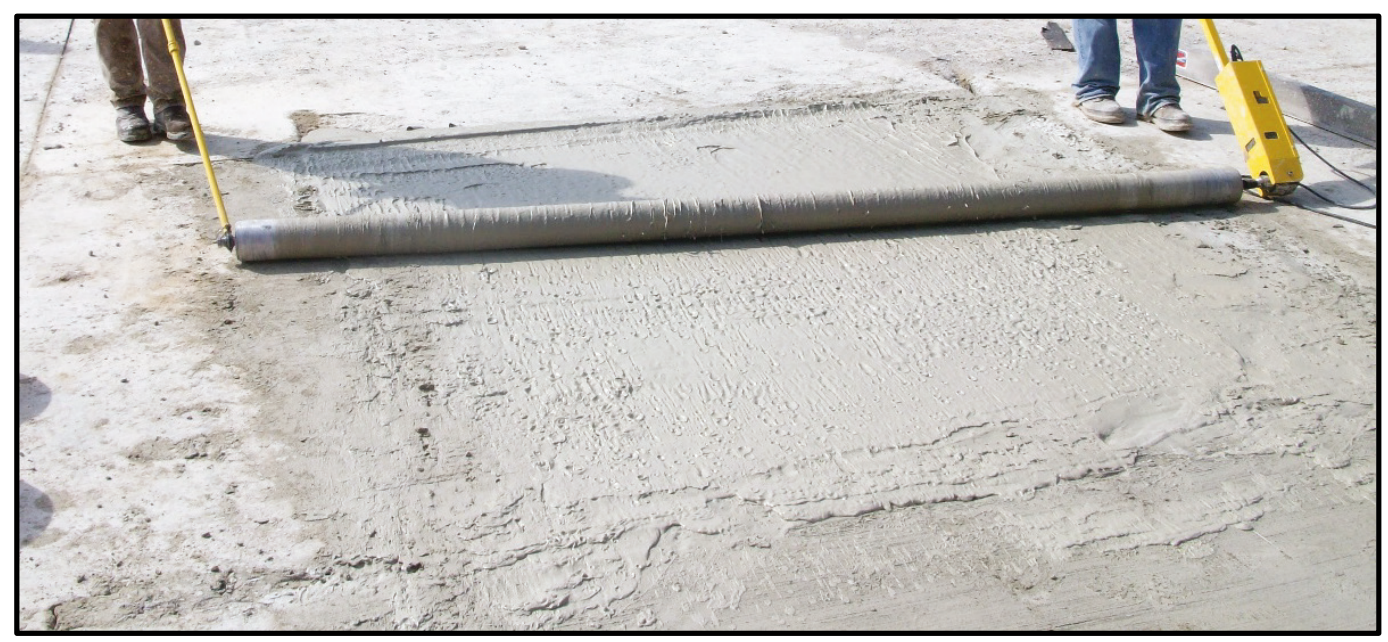

\subsubsection{Vibratory truss screed testing}

The vibratory truss screed (Figure 9) was tested using the included automatic winches to pull the screed across the repair. Setting up the screed was somewhat time consuming, since anchors had to be installed to attach the cable used by the winches and the screed had to be moved into the proper position with equipment. Two pieces of rebar were driven into the ground adjacent to the concrete test area to be used as anchors. For the RADR crater repair process, the winches would likely need to be anchored to the volumetric concrete mixer or mixer prime mover, since drilling anchors would be time consuming in the middle of a surfaced runway, apron, or taxiway. Two personnel were required for screeding, one on each end of the screed to make any necessary adjustments to the winch speed as the screed moved across the repair. These two personnel are shown standing on the screed during operation in Figure 9, but this is not required. Since the winches physically pull the screed across the repair, very little physical exertion was required by the operators. For transporting the screed between repairs, a piece of equipment is required due to the weight of the screed, as discussed in Section 2.1.4. Transporting the screed on a pallet is preferred, since the screed does not have fork pockets and lifting the screed under the top of the truss can cause damage. The additional weight does enable the screed to easily strike off mixtures with a thicker consistency (lower slump) and provide a very smooth finish, as shown in Figure 10. 
Figure 9. Vibratory truss screed testing.

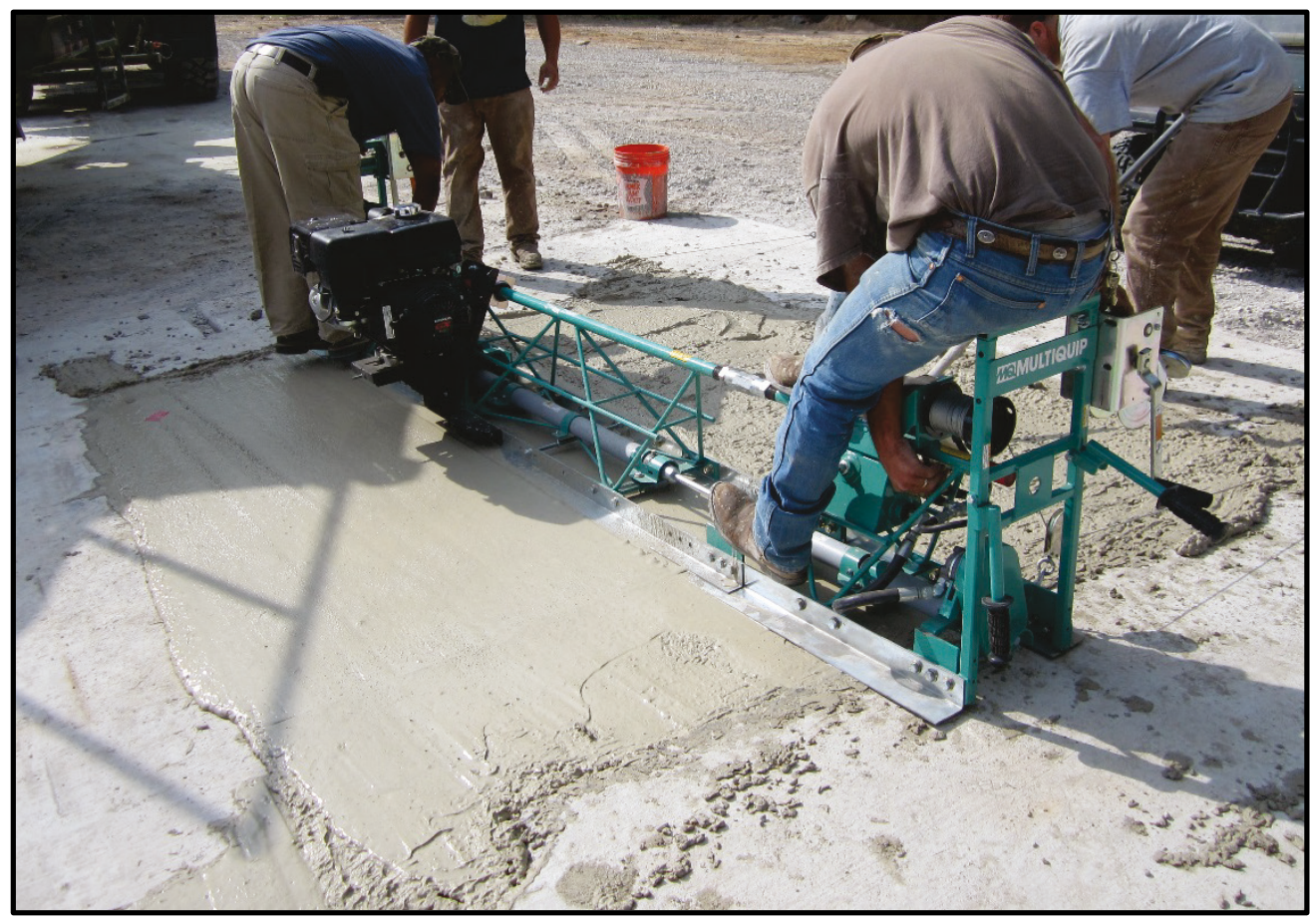

Figure 10. Vibratory truss screed crater repair surface finish.

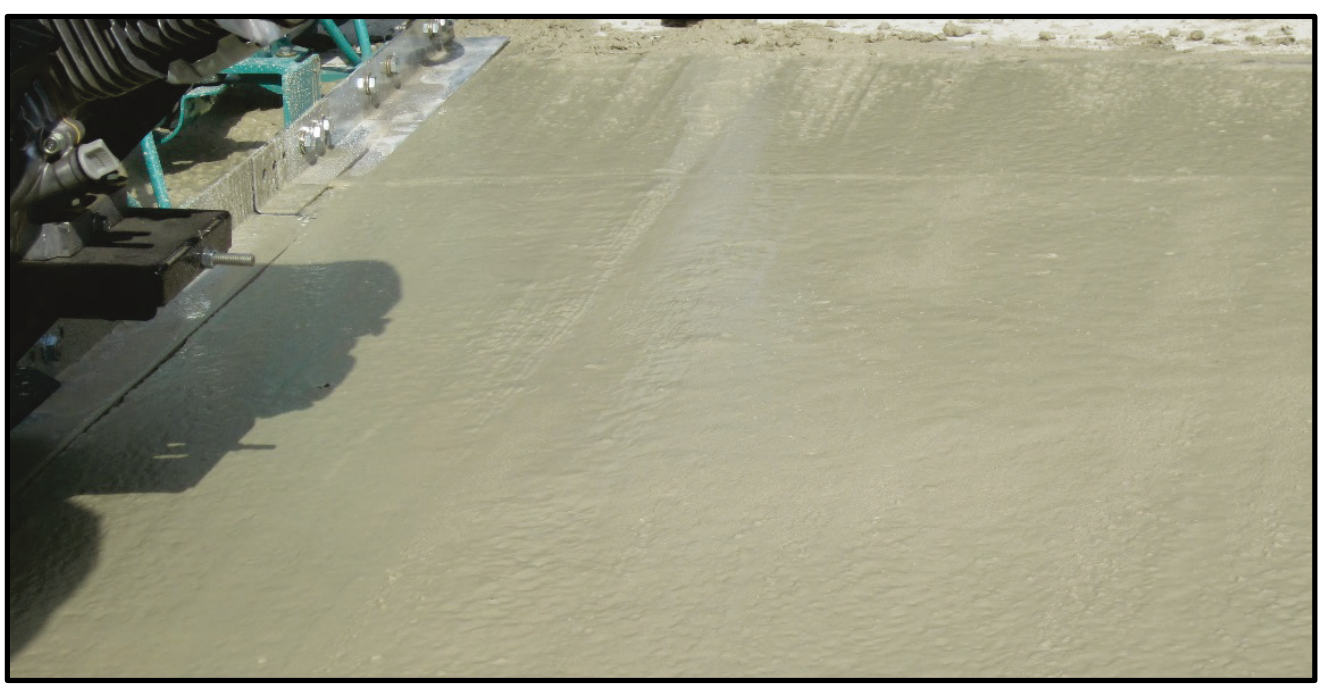

\subsection{5 $\quad$ Autoskreed ${ }^{\circledR}$ testing}

The Autoskreed ${ }^{\circledR}$ was used to screed three repairs, one of which is shown in Figure 11. Some initial setup was required to ensure the Autoskreed ${ }^{\circledR}$ was properly attached to the skid steer, and the electrical cords for the vibrators were connected to the skid steer battery. No additional setup was required between repairs (other than alignment), and the screed was easily transported since it was used as a skid steer attachment. Two to three passes of the Autoskreed ${ }^{\circledR}$ were required to create a flush repair for each 
test. The vibrating screed bar, coupled with the hydraulically powered reach, enabled the device to remove any higher areas of material easily. The Autoskreed ${ }^{\circledR}$ did have the highest average screed time but was less burdensome than the vibratory screed, the magnesium bar screed, and the roller screed, while being much easier to set up than the vibratory truss screed. Virtually no exertion was required by the operators, since the screed is moved back and forth by hydraulic power.

One improvement that is suggested is to increase the speed of reach, as each extension across the crater before screeding took approximately 1 min. Modifications must also be made to enable the Autoskreed ${ }^{\circledR}$ to be compatible with an extendable boom forklift, since that vehicle is projected as the preferred prime mover for the screed within the ADR crater repair process. Recommended changes to the Autoskreed ${ }^{\circledR}$ are detailed in section 4.2 of this report.

Figure 11. Autoscreed ${ }^{\circledR}$ testing.

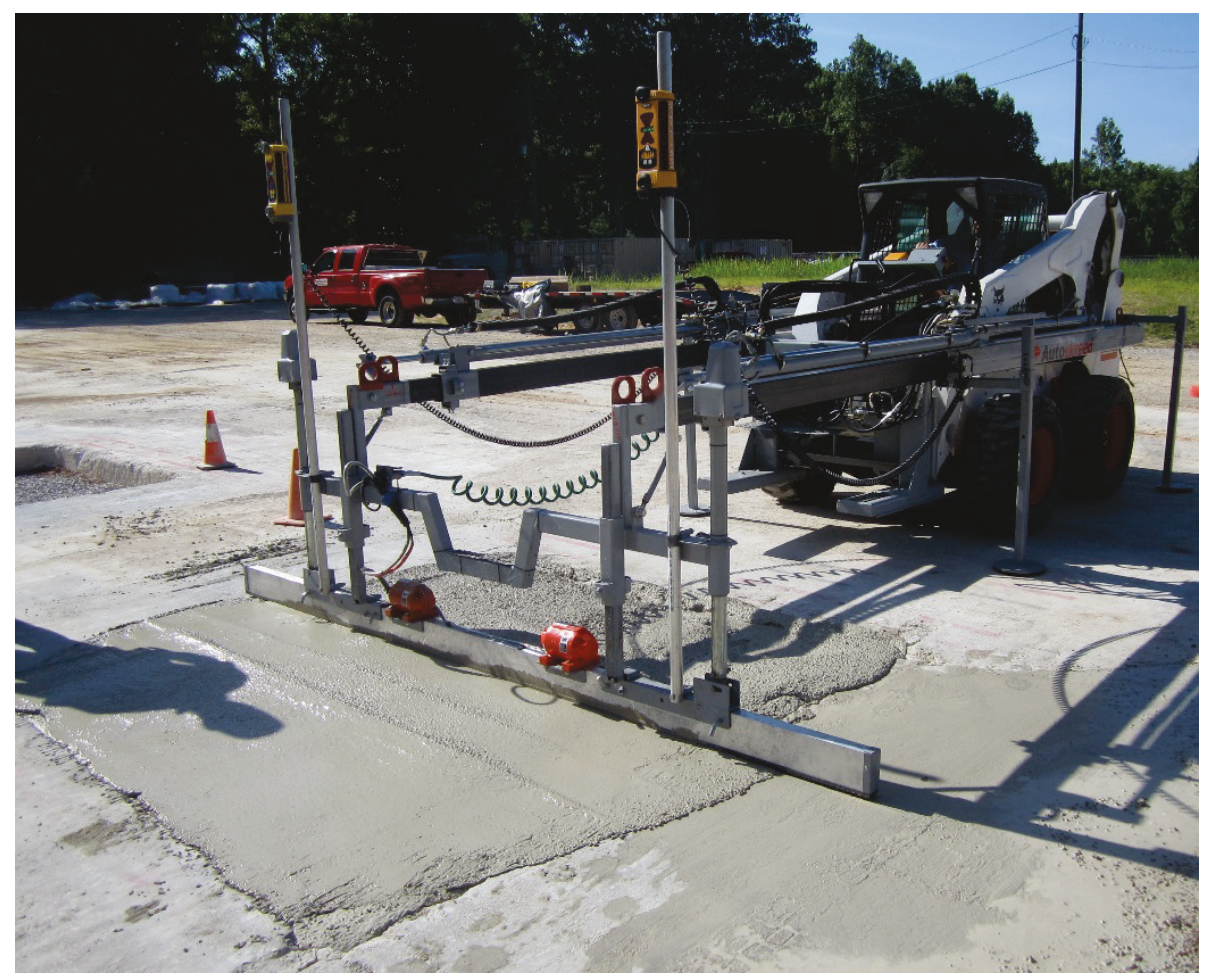

Elevation measurements of two Autoskreed ${ }^{\circledR}$ repairs were obtained to ensure the repairs met Air Force RQC for a flush repair. The repairs must be at least within $+0.5 /-1.0$ in of the surrounding pavement. The surveying layout shown in Figure 12 was used. Table 5 shows the surveying results for both Autoskreed ${ }^{\circledR}$ repairs. The direction of the north $(\mathrm{N})$, center $(\mathrm{C})$, 
and south (S) lines was in the direction of the primary slope of the pavement section, whereas the cross-section (CS) line was on a flatter slope. Survey points 1-7 and survey points 7-13 were analyzed separately for the N, C, and S lines to account for the slope. The two points in each data set that were located outside of the repair were compared to the measurements inside the repair to reveal maximum deviations. For repair 1 , the maximum deviation from the surrounding pavement for the N, C, and $\mathrm{S}$ lines was $0.36 \mathrm{in}$., and the maximum deviation for the CS line was 0.60 in, which is slightly higher than the objective RQC. For repair 2, the maximum deviation was 0.36 in. for both the $\mathrm{N}, \mathrm{C}$, and $\mathrm{S}$ lines and the cross section. All repair 2 measurements met objective RQC.

Figure 12. Autoskreed ${ }^{\circledR}$ surveying layout.

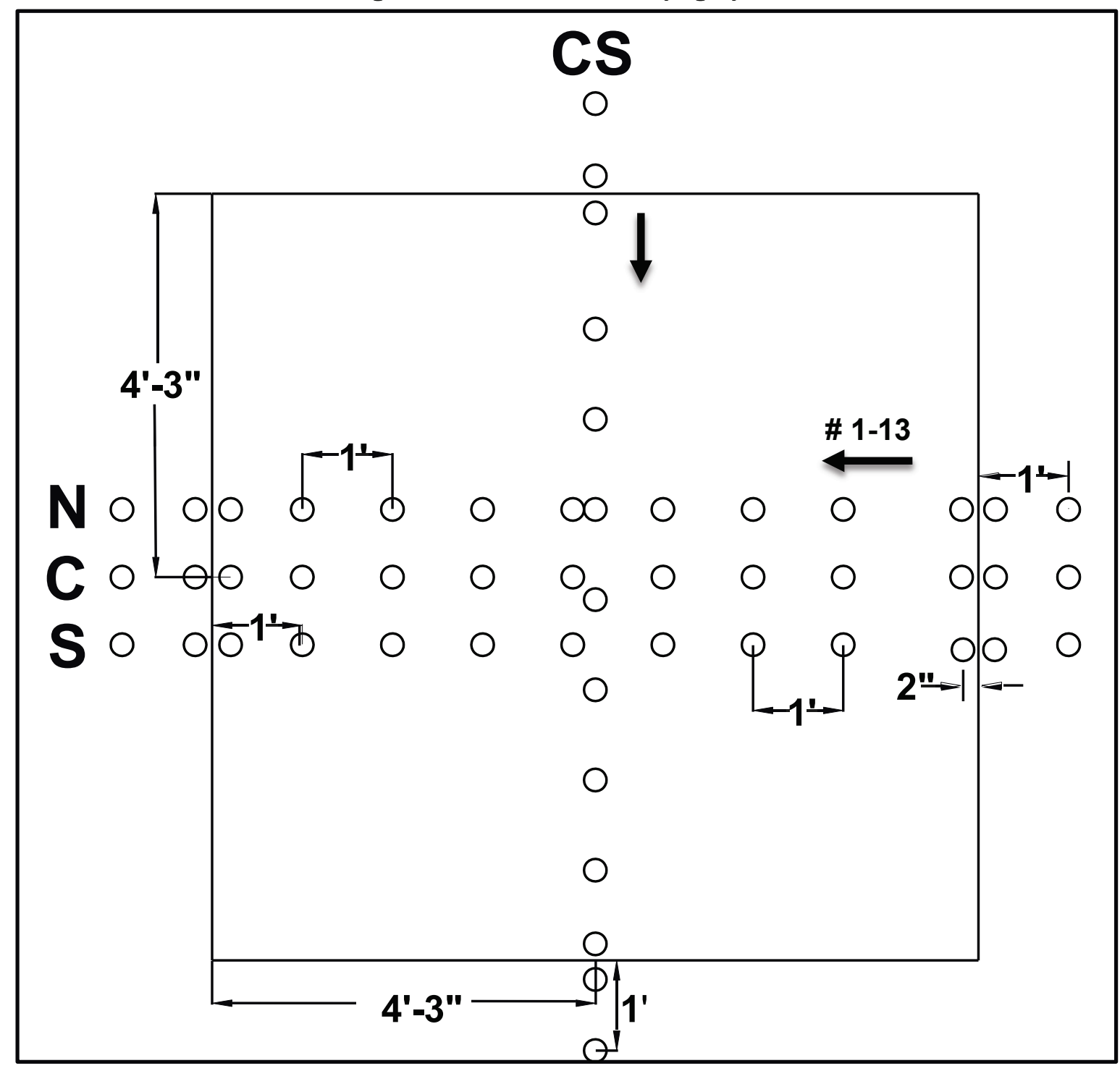


Table 5. Autoskreed ${ }^{\circledR}$ repair survey results.

\begin{tabular}{|c|c|c|c|c|}
\hline \multicolumn{5}{|c|}{ Repair 1} \\
\hline Survey Pt \# & $N(\mathrm{ft})$ & $C(\mathrm{ft})$ & $S(\mathrm{ft})$ & $\mathrm{CS}(\mathrm{ft})$ \\
\hline 1 & 5.27 & 5.27 & 5.27 & 5.26 \\
\hline 2 & 5.27 & 5.27 & 5.27 & 5.26 \\
\hline 3 & 5.25 & 5.24 & 5.25 & 5.24 \\
\hline 4 & 5.25 & 5.24 & 5.25 & 5.24 \\
\hline 5 & 5.25 & 5.24 & 5.25 & 5.24 \\
\hline 6 & 5.25 & 5.24 & 5.24 & 5.24 \\
\hline 7 & 5.24 & 5.24 & 5.24 & 5.23 \\
\hline 8 & 5.22 & 5.22 & 5.23 & 5.23 \\
\hline 9 & 5.23 & 5.22 & 5.23 & 5.23 \\
\hline 10 & 5.22 & 5.21 & 5.22 & 5.22 \\
\hline 11 & 5.22 & 5.20 & 5.21 & 5.24 \\
\hline 12 & 5.22 & 5.22 & 5.23 & 5.27 \\
\hline 13 & 5.22 & 5.22 & 5.23 & 5.27 \\
\hline \multicolumn{5}{|c|}{ Repair 2} \\
\hline Survey Pt \# & $N(\mathrm{ft})$ & $C(\mathrm{ft})$ & $S(\mathrm{ft})$ & $\mathrm{CS}(\mathrm{ft})$ \\
\hline 1 & 5.15 & 5.15 & 5.16 & 5.13 \\
\hline 2 & 5.14 & 5.15 & 5.15 & 5.13 \\
\hline 3 & 5.14 & 5.15 & 5.15 & 5.14 \\
\hline 4 & 5.15 & 5.15 & 5.15 & 5.14 \\
\hline 5 & 5.14 & 5.15 & 5.14 & 5.15 \\
\hline 6 & 5.13 & 5.14 & 5.14 & 5.14 \\
\hline 7 & 5.14 & 5.14 & 5.14 & 5.14 \\
\hline 8 & 5.14 & 5.14 & 5.14 & 5.14 \\
\hline 9 & 5.13 & 5.13 & 5.14 & 5.14 \\
\hline 10 & 5.13 & 5.13 & 5.13 & 5.15 \\
\hline 11 & 5.12 & 5.12 & 5.12 & 5.12 \\
\hline 12 & 5.12 & 5.12 & 5.12 & 5.13 \\
\hline 13 & 5.12 & 5.12 & 5.11 & 5.14 \\
\hline
\end{tabular}

\subsection{Summary of screed results and observations}

During testing speed, ease of use, ease of transport, exertion level of operators, and quality of finish were all observed for each screed, and these parameters were discussed for each screed in the previous section. All screeds tested were ranked based on these parameters, along with cost, as a way of quantifying these observations. Table 6 provides the individual ranks, along with the average rank for each screed. A ranking of one is the best ranking, while a ranking of five is the worst ranking. The speed rankings are based on the data presented in Section 3.1, cost rankings are based on the costs provided in Section 2.1, and the other categories are 
subjective rankings developed from operator surveys and visual observations during testing. The size of the screed was considered in ease of transport rankings. The smaller screeds should be able to be moved without equipment, while the larger ones require equipment. However, the amount of time needed to move the screeds using equipment was considered. For example, the truss screed and the Autoskreed ${ }^{\circledR}$ both required equipment, but the truss screed must be lifted and carefully moved by a forklift, whereas the Autoskreed ${ }^{\circledR}$ is connected to the skid steer as an attachment and can be moved easily once screeding is complete. Overall, the magnesium bar screed had the highest ranking, with the manual vibratory screed, roller screed, and Autoskreed ${ }^{\circledR}$ tied for second. The truss screed had the lowest ranking.

Table 6. Screed rankings.

\begin{tabular}{|c|c|c|c|c|c|}
\hline Parameter & $\begin{array}{c}\text { Manual } \\
\text { Vibratory }\end{array}$ & $\begin{array}{c}\text { Magnesium } \\
\text { Bar }\end{array}$ & Roller & Truss & Autoskreed $^{\circledR}$ \\
\hline Speed & 3 & 2 & 1 & 4 & 5 \\
\hline Ease of Setup \& Operation & 2 & 1 & 3 & 5 & 4 \\
\hline Ease of Transport & 3 & 2 & 4 & 5 & 1 \\
\hline Exertion Level of Operator(s) & 4 & 5 & 3 & 2 & 1 \\
\hline Cost & 3 & 1 & 2 & 4 & 5 \\
\hline Quality of Finish & 3 & 4 & 5 & 1 & 2 \\
\hline Average & 3.0 & 2.5 & 3.0 & 3.5 & 3.0 \\
\hline
\end{tabular}




\section{Conclusions and Recommendations}

The primary objective of screed testing was to evaluate commercially available screeds for finishing rapid-setting concrete. To carry out this objective, several screeds were evaluated for speed of finishing, ease of use and setup, ease of transport, exertion level of operator(s), and quality of finish produced. The following sections provide conclusions developed from testing along with the corresponding recommendations.

\subsection{Conclusions}

- The manual vibratory screed was easy to set up, operate, and transport and provided an adequate finish but required a large amount of exertion from three operators. The screed time was also relatively high compared to other screeds, and the cost was moderately high. Overall, the screed finished tied for second in the screed rankings shown in Table 6.

- The magnesium bar screed had the lowest cost and was easy to transport and operate with two personnel. However, exertion level of the operators is directly related to the consistency of the rapid-setting material. Material with a less fluid consistency makes screeding more difficult. The screed also requires the most exertion from the operators. Overall the screed finished first in the screed rankings shown in Table 6.

- The roller screed was easy to operate, required only two personnel with little exertion, and exhibited the fastest screed time. However, the roller screed produced the lowest quality finish of any of the screeds and was moderately cumbersome to set up and transport. Overall the roller screed finished tied for second in the screed rankings shown in Table 6.

- The vibratory truss screed provided the best finish with only a small amount of exertion by the operators but was difficult to transport, set up, and operate. Two personnel, along with a vehicle, were required to move the screed. Anchor points were also required to attach the winches that pull the screed across the repair. Overall, the truss screed finished last in the screed rankings shown in Table 6.

- The Autoskreed ${ }^{\circledR}$ required the least exertion from the operator, provided a quality finish, and was the only screed tested that is capable of being operated by one person. However, the Autoskreed ${ }^{\circledR}$ also exhibited the longest screed time and the highest cost and was 
somewhat difficult to set up. Recommendations for modification to the Autoskreed ${ }^{\circledR}$ are discussed in Section 4.2.

- Autoskreed ${ }^{\circledR}$ survey measurements indicated that repair 1 had one location that was 0.1 in outside RQC. All repair 2 measurements were within RQC. Overall, results indicated that the Autoskreed ${ }^{\circledR}$ is capable of finishing repairs that will likely meet RQC.

\subsection{Recommendations}

- The vibratory manual screed is recommended to be included in ADR tool kits due to its satisfactory performance in previous ADR demonstrations and during the testing described in this report.

- The magnesium bar screed is recommended to be included in ADR tool kits as an alternative to automated screeds. The magnesium bar screed performs satisfactorily when rapid-setting concrete is placed at normal consistency, is easily transported between repairs, and takes up very little space in typical tool kit layouts.

- Further modification could improve the magnesium bar screed's ease of use. Handles should be included to make the screed easier to grip during operation.

- The Autoskreed ${ }^{\circledR}$ was the only commercially available screed capable of attaching to equipment and being operated by one person. Therefore, it is recommended that the Autoskreed ${ }^{\circledR}$ be pursued as a potential screed solution for ADR crater repair activities. However, several modifications are recommended:

- The Autoskreed ${ }^{\circledR}$ should be attachable to the standard forklift that will be used for the ADR base recovery process. The current screed attaches to a skid steer loader, and these will be less accessible than the forklift during ADR operations. The screed should be capable of using the forklift's reach to move back and forth and not its own hydraulically powered reach.

- The Autoskreed ${ }^{\circledR}$ should be properly and easily secured to the forklift cage to ensure stability during screeding.

- The Autoskreed ${ }^{\circledR}$ bar length should be capable of screeding crater repairs up to $15 \mathrm{ft}$ in width. An extendable bar or multiple bars that can be changed out quickly are both acceptable options. 


\section{References}

Air Force Civil Engineer Center (AFCEC). 2018. Interim tactics, techniques, and procedures: Rapid Airfield Damage Repair (RADR) interim process for base recovery after attack. Tyndall AFB, FL: AFCEC.

Bell, H. P. 2017. Inclement weather crater repair tool kit. ERDC/GSL TR-17-26. Vicksburg, MS: U.S. Army Engineer Research and Development Center.

Bell, H. P., C. L. Dean, and C. A. Rutland. 2018. Wet weather crater repair methods for grooved and smooth pavements. ERDC/GSL TR-18-6. Vicksburg, MS: U.S. Army Engineer Research and Development Center.

Bell, H. P., L. Edwards, W. D. Carruth, J. S. Tingle, and J. R. Griffin. 2013. Wet weather crater repair testing at Silver Flag Exercise Site, Tyndall Air Force Base, Florida. ERDC/GSL TR-13-42. Vicksburg, MS: U.S. Army Engineer Research and Development Center.

Bell, H. P., L. P. Priddy, Q. S. Mason, and C. A. Rutland. 2015. Concrete cutting refinement for crater repair. ERDC/GSL TR-13-42. Vicksburg, MS: U.S. Army Engineer Research and Development Center.

Bell, H. P. and J. Rowland. 2017. Next generation airfield damage repair: Deployable saw technologies. ERDC/GSL TR-17-26. Vicksburg, MS: U.S. Army Engineer Research and Development Center.

Carruth, W. D., L. Edwards, H. P. Bell, J. S. Tingle, J. R. Griffin, and C. A. Rutland. 2015. Large crater repair at Silver Flag exercise site, Tyndall Air Force Base, Florida. ERDC/GSL TR-15-27. Vicksburg, MS: U.S. Army Engineer Research and Development Center.

Carruth, W. D., and I. L. Howard. 2016. Evaluation of flowable fill surface performance. ERDC/GSL TR-16-33. Vicksburg, MS: U.S. Army Engineer Research and Development Center.

Edwards, L., H. P. Bell, W. D. Carruth, J. R. Griffin, and J. S. Tingle. 2013. Cold weather crater repair testing at Malmstrom Air Force Base, Montana. ERDC/GSL TR13-32. Vicksburg, MS: U.S. Army Engineer Research and Development Center.

Edwards, L., W. D. Carruth, J. S. Tingle, and I. L. Howard. 2018. Rapid-setting flowable fill performance in cold weather for airfield damage repair. ERDC/GSL TR-1826. Vicksburg, MS: U.S. Army Engineer Research and Development Center.

Gartrell, C. A. 2007. Investigations for airfield damage repair kit modifications and improvements. ERDC/GSL TR-07-16. Vicksburg, MS: U.S. Army Engineer Research and Development Center.

Gartrell, C. A. 2008. Investigations for airfield damage repair kit modifications and improvements, phase II. ERDC/GSL TR-08-09. Vicksburg, MS: U.S. Army Engineer Research and Development Center. 
Priddy, L. P., H. P. Bell, L. Edwards, W. D. Carruth, and J. F. Rowland. 2016. Evaluation of the structural performance of Rapid Set Concrete Mix®. ERDC/GSL TR-1620. Vicksburg, MS: U.S. Army Engineer Research and Development Center.

Priddy, L. P., J. R. Griffin, and J. S. Tingle. 2011. Live-flight certification testing of CRATR technologies, Avon Park Air Force Range, Florida. ERDC/GSL TR 11-7. Vicksburg, MS: U.S. Army Engineer Research and Development Center.

Priddy, L. P., J. S. Tingle, M. C. Edwards, J. R. Griffin, and T. J. McCaffrey. 2013a. Critical Runway AssessmenT and Repair (CRATR) technology demonstration: Limited Operational Utility Assessment 2 (LOUA2), Tyndall Air Force Base, Florida. ERDC/GSL-13-39. Vicksburg, MS: U.S. Army Engineer Research and Development Center.

Priddy, L. P., J. S. Tingle, J. R. Griffin, M. C. Edwards, and T. J. McCaffrey. 2013b. Critical Runway AssessmenT and Repair (CRATR) technology demonstration: Operational Utility Assessment (OUA), Avon Park Air Force Range, Florida. ERDC/GSL TR-13-33. Vicksburg, MS: U.S. Army Engineer Research and Development Center.

Priddy, L. P., J. S. Tingle, T. J. McCaffrey, and R. S. Rollings. 2007. Laboratory and field investigations of small crater repair technologies. ERDC/GSL TR-07-27. Vicksburg, MS: US Army Engineer Research and Development Center.

Tingle, J. S., L. P. Priddy, C. Gartrell, M. Edwards, and T. J. McCaffrey. 2009. Critical Runway AssessmenT and Repair (CRATR) Limited Operational Utility Assessment 1 (LOUA1), Tyndall Air Force Base, FL. ERDC/GSL-09-12. Vicksburg, MS: U.S. Army Engineer Research and Development Center.

United States Air Force (USAF). 1992. Crushed-stone cater repair and line-of-sight profile measurement for rapid runway repair. TO 35E2-5-1. Washington, DC: United States. 


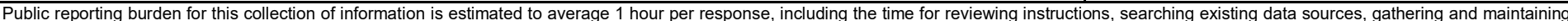

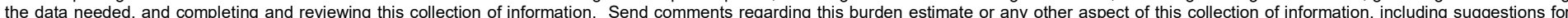

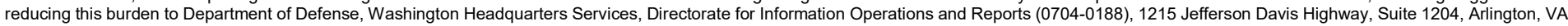

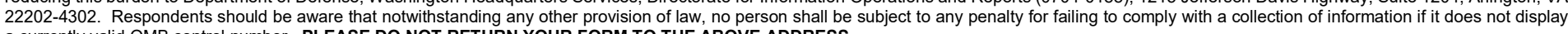
a currently valid OMB control number. PLEASE DO NOT RETURN YOUR FORM TO THE ABOVE ADDRESS.
1. REPORT DATE (DD-MM-YYYY) 2. REPORT TYPE
3. DATES COVERED (From - To)

February 2019 Final

\section{TITLE AND SUBTITLE}

Evaluation of Commercially Available Screeds for Finishing of Rapid-Setting

Concrete

\section{5a. CONTRACT NUMBER}

\section{5b. GRANT NUMBER}

5c. PROGRAM ELEMENT NUMBER

\section{AUTHOR(S)}

William D. Carruth

\section{5d. PROJECT NUMBER}

369676

5e. TASK NUMBER

5f. WORK UNIT NUMBER

\section{PERFORMING ORGANIZATION NAME(S) AND ADDRESS(ES)}

Geotechnical and Structures Laboratory

U.S. Army Engineer Research and Development Center

3909 Halls Ferry Road

Vicksburg, MS 39180-6199

\section{SPONSORING / MONITORING AGENCY NAME(S) AND ADDRESS(ES)}

Headquarters, Air Force Civil Engineer Center

Tyndall AFB, FL 32403-5319

ERDC/GSL TR-19-4
8. PERFORMING ORGANIZATION REPORT NUMBER
10. SPONSOR/MONITOR'S ACRONYM(S)

AFCEC

11. SPONSOR/MONITOR'S REPORT NUMBER(S)

\section{DISTRIBUTION / AVAILABILITY STATEMENT}

Approved for public release; distribution is unlimited.

\section{SUPPLEMENTARY NOTES}

\section{ABSTRACT}

The U.S. Air Force Civil Engineer Center (AFCEC) began the Rapid Air-field Damage Recovery (RADR) Modernization Program to develop tech-nologies to address operational limitations of current RADR equipment, materials, and tactics. One of the most critical activities in the crater re-pair process is the finishing of rapid-setting concrete material used to cap repairs. Finished repairs must meet roughness quality criteria (RQC) in order to prevent damage to fighter aircraft. The concrete screeds used previously were consistently able to meet this criteria, however they re-quired three dedicated personnel to operate. The quantity of crater repair team members is limited, so AFCEC desires a reduction in manpower re-quirements for rapid-setting concrete finishing. To address this shortfall, five commercially available screeds were evaluated by conducting a total of 14 crater repairs. Screeds were ranked according to the following at-tributes: (1) speed, (2) ease of setup and operation, (3) ease of transport, (4) operator exertion level, (5) cost, and (6) quality of finish. The number of personnel required to operate each screed was also recorded. The Au-toSkreed ${ }^{\circledR}$ was recommended for consideration as a suitable screed, but several modifications are recommended. The vibratory manual screed and magnesium bar screed were recommended as preferred alternatives.

\begin{tabular}{|ll}
\hline 15. SUBJECT TERMS & Crater repair \\
Airfield Damage Repair & Base recovery \\
Rapid-setting concrete & Runways (Aeronautics)-Maintenance and Repair \\
Pavements & Concrete
\end{tabular}

16. SECURITY CLASSIFICATION OF:

\begin{tabular}{|l|l|}
\hline a. REPORT & b. ABSTRACT \\
Unclassified & Unclassified \\
& \\
\hline
\end{tabular}

\section{Military bases}

Air bases

Runways (Aeronautics) - Maintenance and repair Concrete construction - Equipment

17. LIMITATION
OF ABSTRACT

18. NUMBER OF PAGES

37 19a. NAME OF RESPONSIBLE PERSON

19b. TELEPHONE NUMBER (include area code) 